\title{
Kształtowanie się regionów przemysłowych Francji
}

Celem opracowania jest przedstawienie procesu różnicowania się przestrzeni Francji metropolitarnej $\mathrm{w}$ odniesieniu do przemian zachodzących $\mathrm{w}$ działalności przemysłowej od XVIII w. do końca XX w. W badaniach oparto się na danych statystycznych zawartych w rocznikach statystycznych i innych publikowanych materiałach.

W związku z rozbieżnościami w odniesieniu do terminu region, w poniższym tekście traktowany on będzie jako jednostka posiadająca pewną specjalizację produkcyjno-usługową w ramach całego kraju (Fajferek 1964), i określany również mianem rejonu.

Niezależnie od definicji regionu większość badaczy jest zgodna co do znaczenia historii w kształtowaniu się współczesnych układów regionalnych.

Gdy we Francji pojawiło się zróżnicowane rolnictwo, w geografii tradycyjnego przemysłu nie istniała żadna specjalizacja. Przemysł Francji charakteryzował się rozrzuconymi małymi przedsiębiorstwami wykorzystującymi jedynie surowe materiały i lokalne źródła energii.

Do XIX w. w działalności produkcyjnej przeważały warsztaty rzemieślnicze, które można podzielić na trzy typy. Pierwszą grupę stanowiły małe warsztaty rzemieślnicze, których działalność skupiała się na obszarach o dużej gęstości zaludnienia w stosunku do powierzchni użytków rolnych. Były to północne regiony Francji: Flandria, Pikardia, Artois, Górna Normandia, Ardeny oraz regiony górskie (Cobban 1965). Ta spontaniczna wytwórczość oparta na lokalnej bazie surowcowej charakteryzowała się głównie produkcją na rynek wewnętrzny.

Natomiast tam, gdzie konieczny był import surowców oraz specjalizacja w cyklu produkcyjnym rozwinęła się bardziej zorganizowana forma działalności produkcyjnej. Były to rozproszone przestrzennie warsztaty powiązane wertykalnie. Ten typ wytwórczości występował głównie w przemyśle włókienniczym Północy oraz Szampanii, Burgundii i Normandii. Innym regionem był Lyon, gdzie przemysł jedwabniczy został przez handlowców rozdzielony pomiędzy różne powiązane ze sobą warsztaty mieszczące się w granicach miasta.

Trzecim rodzajem przemysłu były fabryki powstające głównie z inicjatywy odgórnej, w celu zmniejszenia zależności od importowanych, głównie luksusowych towarów. Fabryki te powstawały głównie w regionie Île-de-France w okolicach Paryża oraz doliny Loary.

Wraz z rozwojem szlaków komunikacyjnych i postępem technologicznym następowała powolna koncentracja przemysłu. Przykładem może być przemysł hutniczy i włókienniczy. Lokalizacja przemysłu hutniczego zdeterminowana była występowaniem rud żelaza, zasoba- 
mi energetycznymi (drewno) oraz siłą wody związanej z działalnością kuźni. Zakłady metalurgiczne lokalizowano na obszarze od Ardenów i Basenu Paryskiego na północy po Masyw Centralny, Jurę i Alpy na południu oraz we wschodnich Pirenejach. W 1778 r. w Le Creusot - Burgundia powstała spółka hutnicza, a samo miasto stało się największym zagłębiem górniczo-hutniczym Francji. Innym okręgiem przemysłu metalurgicznego Francji był Lyon oraz inne miejscowości skupione w promieniu około $100 \mathrm{~km}$ od niego (Braudel 1992).
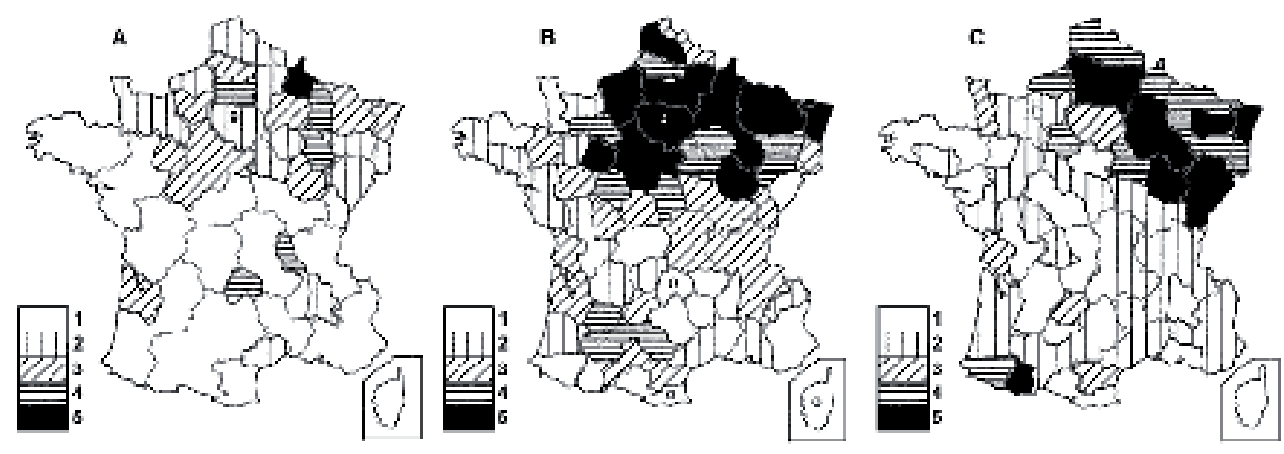
A. Rzemieślnicy: 1) < 11,88\%; 2) 11,88-15,39\%; 3) 15,40-18,29\%; 4) 18,30-21,74\%; 5) >21,74\%;
B. Kołodzieje: 1) <0,20\%; 2) 0,20-0,47\%; 3) 0,48-0,80\%; 4) 0,81-1,36\%; 5) >1,36\%;
C. Inteligenci (nauczyciele, studenci itp.): 1) $<0,28 \%$; 2) $0,28-0,47 \%$; 3) $0,48-0,80 \%$; 4) $0,81-1,36 \%$; 5 ) >1,36\%

Ryc. 1. Zatrudnienie mężczyzn według spisu poborowych 1819-1826

Źródło: Planhol 1994, s. 157

Głównym napędem przemysłu Francji był przemysł włókienniczy. W XVIII w. występował on w trzech regionach: Pikardia-Normandia, Szampania (razem około 50\% produkcji krajowej) i Langwedocja (około 30\% produkcji). Przemysł lniany skoncentrowany był ze względów klimatycznych na północy, w regionie Bretanii, Normandii, Pikardii i Nord. Przemysł jedwabniczy, uzależniony od importu, rozwinął się w Tureni, Dolnej Langwedocji, dolinie Rodanu, Prowansji i Lyonie. Również przemysł bawełniany, uzależniony od dostaw z posiadłości zamorskich, rozwinął się wokół portów Rouen, Bordeaux i Nantes oraz w miastach Prowansji, Langwedocji i w regionie Lyonu. Przemysł bawełniany rozprzestrzenił się również na północy w Dolnej Normandii, Pikardii i regionie Paryża.

Pomimo braku wyraźnych różnic w strukturze przemysłu Francji do XVIII w. można stwierdzić, że obszary północny i wschodni charakteryzowały się większym uprzemysłowieniem niż południe i zachód Francji. Poza regionem Paryża i doliny Sekwany przemysł skupiony był w regionie Lyonu i w Prowansji, w tym głównie wokół Marsylii. Innymi regionami o wysokiej koncentracji tradycyjnego przemysłu były gęsto zaludnione tereny Flandrii oraz regiony górskie, głównie gór średnich. Rozwój przemysłu w regionach górskich wywołany był dostępnością energii (woda i drewno), zasobnością tych terenów w złoża mineralne oraz wełnę i skóry. Inną przyczyną była dostępność siły roboczej spowodowana małą produktywnością rolnictwa oraz krótkim okresem wegetacji. Spośród branż w regionach górskich dominował przemysł górniczy i metalurgiczny, który rozwinął się w górnych odcinkach dolin. Natomiast małe warsztaty rozrzucone były w strefie podgórskiej. Sytuacja ta występowała 
w Wogezach, Jurze, w strefie przedalpejskiej oraz w Pirenejach (Ariège). Spośród regionów górskich Masyw Centralny był najmniej uprzemysłowiony; złoża mineralne eksploatowane były tu już w czasach celtyckich. W regionie tym rozwinął się przemysł włókienniczy: wełniany na południu Masywu Centralnego i w Sewennach oraz konopny.

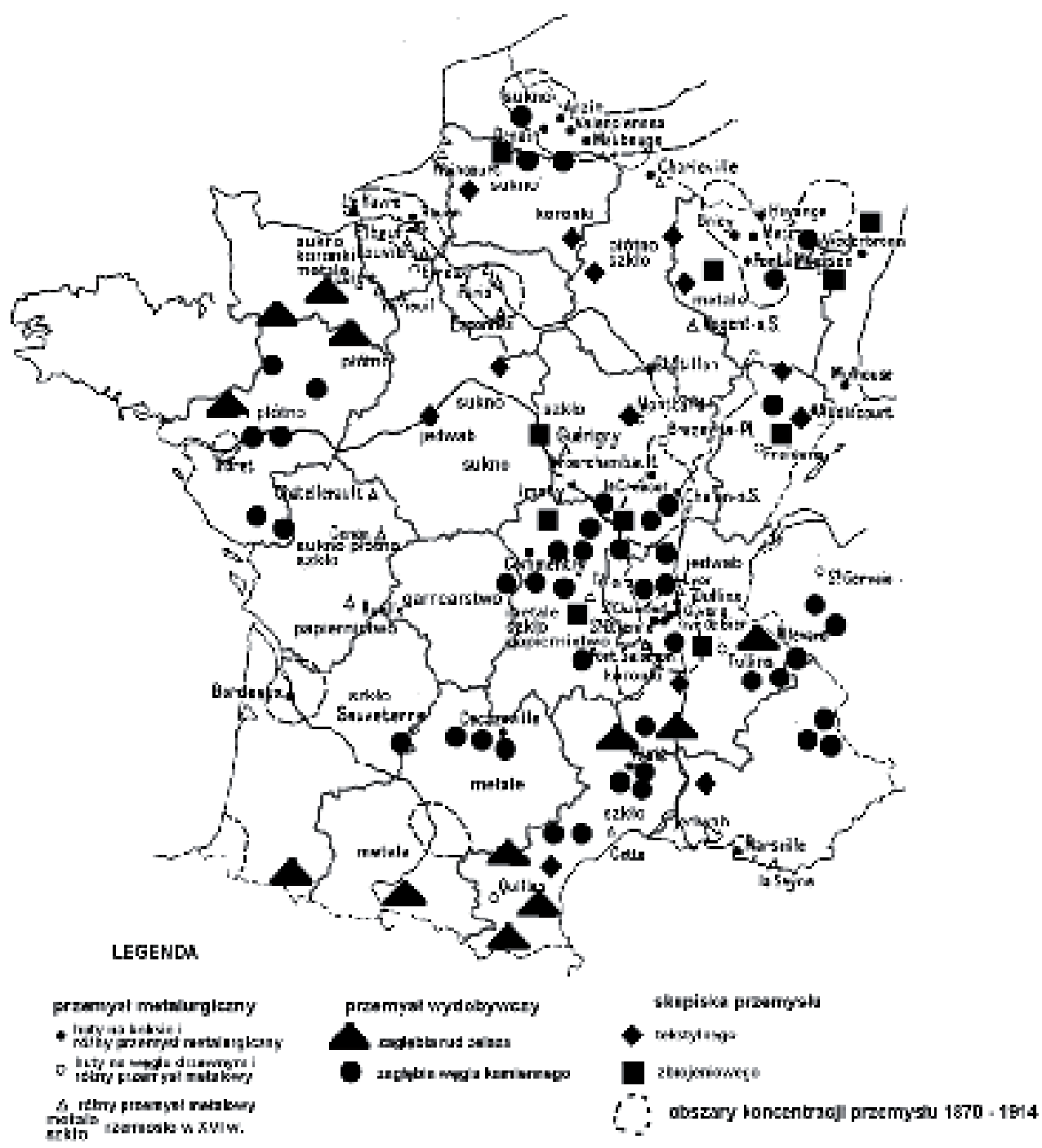

Ryc. 2. Przemysł we Francji w XVIII w.

Źródło: Opracowanie własne na podstawie: Duby 1958 i Maciejewski 1996

Czynnikiem, który rozpoczął proces koncentracji przemysłu, było wynalezienie maszyny parowej. Pierwszą maszynę parową zastosowano we Francji w 1779 r. Biorąc pod uwagę ilość maszyn parowych, w 1841 r. najbardziej uprzemysłowionymi departamentami 
Francji były departamenty regionu Nord, Seine-Maritime oraz region Lyonu (Rhône i Loire). Następne były: region doliny Rodanu i Saony, obszar śródziemnomorski i tereny od Alzacji i Lotaryngii na wschodzie po departament Sommy na północnym zachodzie. Ogólnie departamenty z więcej niż pięcioma maszynami parowymi skupione były na wschód od Masywu Centralnego i na południowy wschód od Sekwany (wyjątkiem na zachodzie były uprzemysłowione departamenty usytuowane w dolnym odcinku ujścia Loary i Wzgórz Normandzkich oraz Gironde). W 1878 r. najwięcej maszyn parowych skupionych było w departamentach regionu Nord, Pikardii, Górnej Normandii oraz Lyonu i Creusot. Powyżej 500 maszyn posiadały departamenty regionu Paryża i Szampanii po Ardeny oraz departamenty położone u ujścia Rodanu i Loary oraz departament Cher. Najmniej uprzemysłowionymi obszarami do końca XIX w. były Alpy, Pireneje oraz Masyw Centralny. W 1898 r. do grupy departamentów z największą liczbą maszyn parowych dołączyła Sabaudia oraz Lotaryngia.

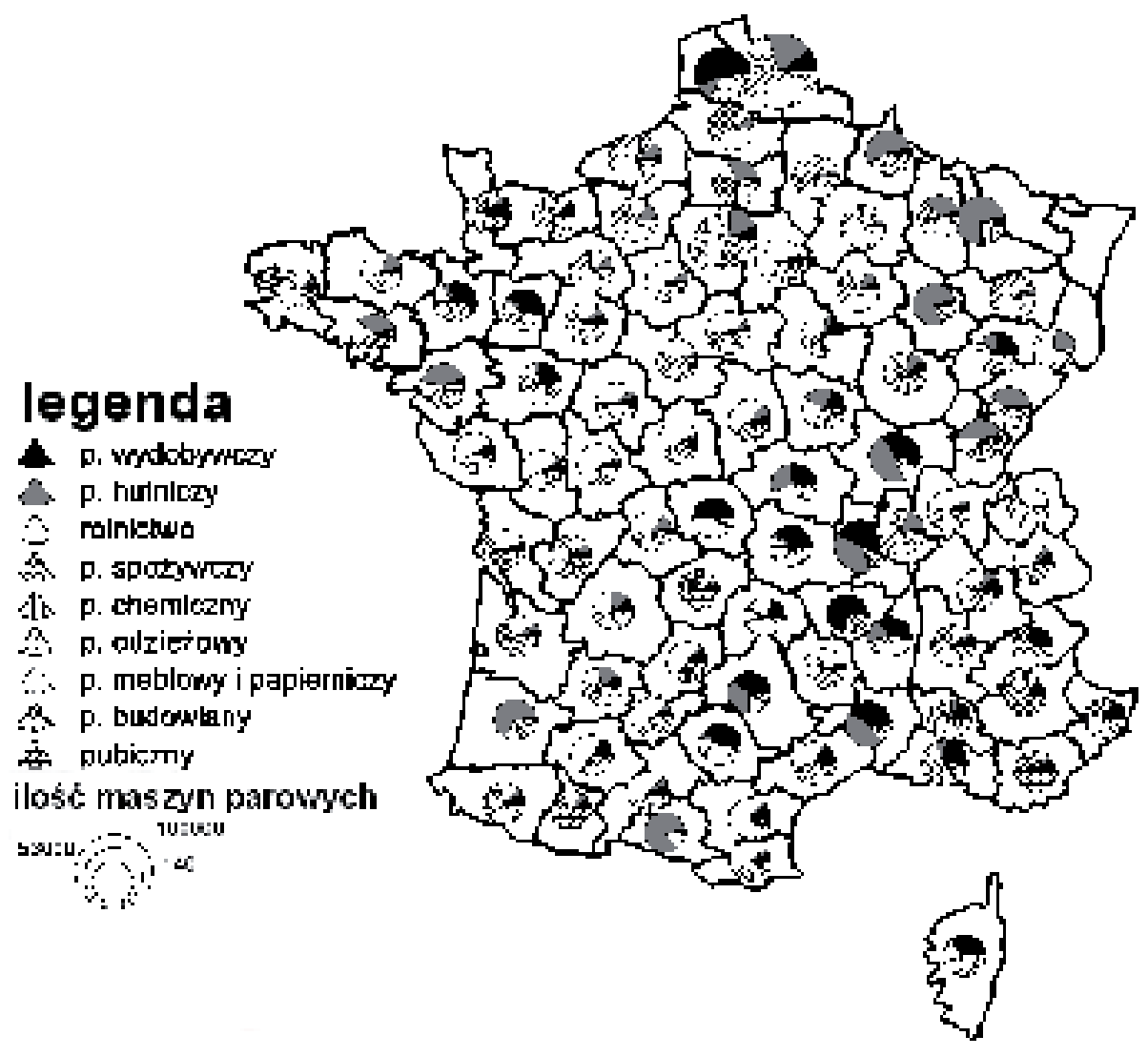

Ryc. 3. Maszyny parowe we Francji w XIX w.

Źródło: Obliczenia własne na podstawie „Annuaire Statistique”

Wraz ze wzrostem liczby maszyn parowych następował wzrost wydobycia węgla, który stał się najważniejszym surowcem energetycznym oraz wpływał na lokalizacje zakładów. W 1875 r. największymi obszarami wydobycia węgla były: region Nord, Lyonu i Langwe- 
docji. Poza regionem północnym węgiel wydobywano na całym terenie południowo-wschodniej Francji od Wogezów na północy poprzez Masyw Centralny i Alpy po wybrzeże Morza Śródziemnego oraz w Pirenejach zachodnich. Ponadto węgiel wydobywano u podstawy Półwyspu Armorykańskiego, od Dolnej Normandii po Wadee.

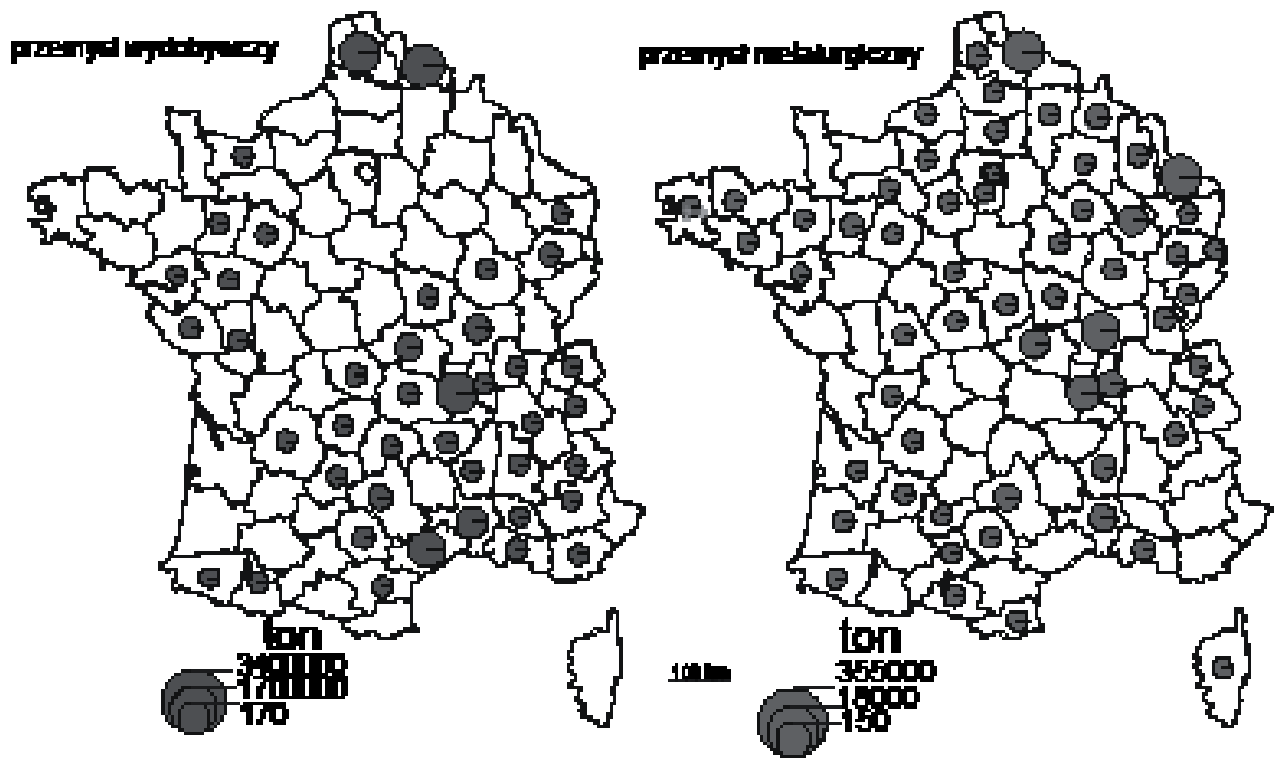

Ryc. 4. Wydobycie paliw kopalnych oraz produkcja metalurgiczna w tonach w $1875 \mathrm{r}$.

Źródło: Obliczenia własne na podstawie „Annuaire Statistique”

To uzależnienie przemysłu od silnika parowego i węgla spowodowało koncentrację przemysłu w regionach bogatych w surowce lub siłę roboczą.

Postęp techniczny w procesie wytopu żelaza i produkcji stali pozwolił na bezpośrednie wykorzystanie złóż metali, co doprowadziło do lokalizacji hut blisko złóż rud. Innowacje dotyczyły głównie użycia po raz pierwszy w 1874 r. konwektora przy wytopie żelaza, co pozwoliło na zastosowanie lotaryńskich złóż rud żelaza (Maciejewski 1996).

Biorąc pod uwagę udział w produkcji przemysłu hutniczego, w czasie Trzeciej Republiki można wyróżnić trzy wielkie regiony przemysłowe: Nord, Lotaryngia i SaintÉtienne-Creusot. Regiony Nord i Lotaryngii wraz z sąsiednimi departamentami wytwarzały ponad połowę produkcji hutniczej. Następny region tworzyły departamenty skupione wokół Le Creusot, wytwarzając ponad $20 \%$ produkcji hutniczej, a z St-Étienne oraz zakładami skupionymi w dolinie Rodanu około $30 \%$ produkcji. Reszta fabryk była rozproszona po całej Francji: w Bretanii, Górnej Normandii, Basenie Paryskim i Akwitańskim.

W przededniu pierwszej wojny światowej nastąpiła dalsza koncentracja przemysłu hutniczego. Zakłady zlokalizowane w Lotaryngii wytwarzały $51 \%$ ogółu produkcji metalurgicznej, a region Nord około $18 \%$. Lokalizacja pozostałych regionów hutniczych pozostawała niezmienna. 


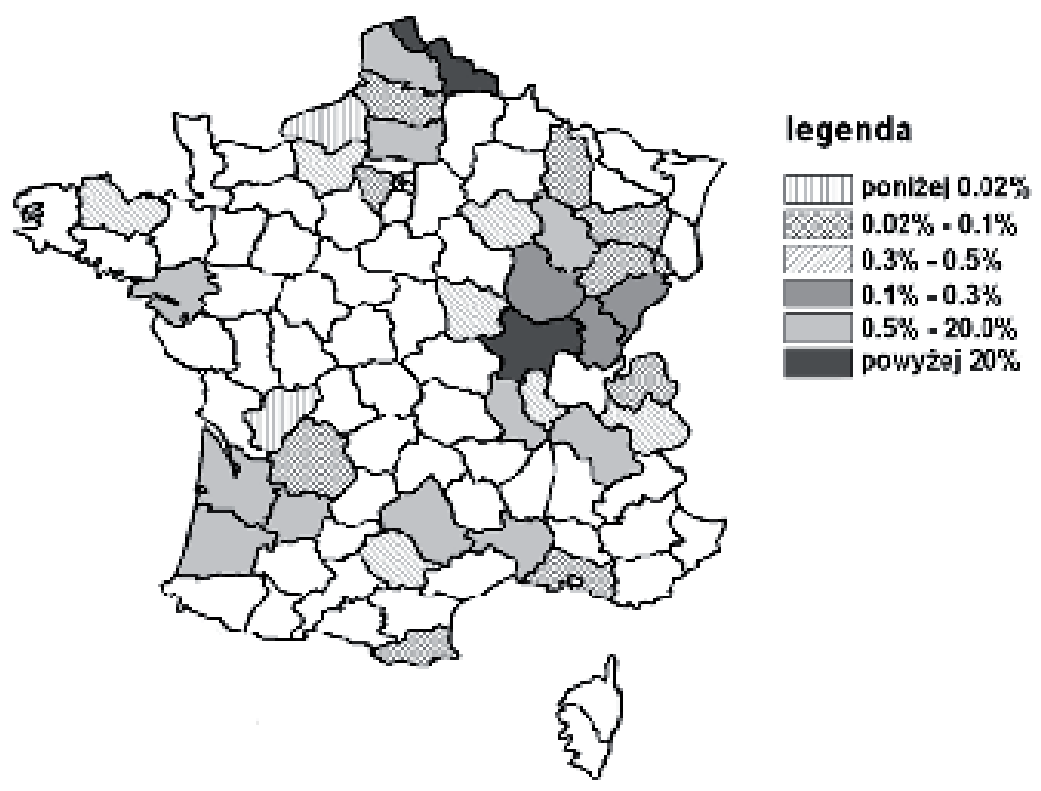

Ryc. 5. Procentowy udział produkcji przemysłu hutniczego we Francji według departamentów w 1909 r.

Źródło: Obliczenia własne na podstawie „Annuaire Statistique”

W latach 1822-1838 Towarzystwo Statystyczne we Francji zarejestrowało 1106 manufaktur (Dunham 1953). Najwięcej fabryk w XIX w. zlokalizowanych było w zachodniej części Francji w regionie Fladrii, Normandii, Pikardii i Île-de-France, w Lotaryngii i Alzacji, w regionie Lyonu i Prowansji. Również w XX w. powyższe regiony wyróżniają się pod względem liczby zakładów, lecz wyraźniej jest to widoczne w odniesieniu do zakładów zatrudniających powyżej 100 pracowników.

Powstanie wielkich fabryk doprowadziło do upadku rzemiosła, jednakże w niektórych regionach, gdzie ludność musiała, z powodu ubogiego rolnictwa, szukać dodatkowego źródła utrzymania, rozwinęły się inne gałęzie przemysłu. Na przykład w Pirenejach, Bretanii i Langwedocji rozwinął się przemysł obuwniczy i tekstylny, w Jurze i Alpach przemysł zegarmistrzowski i metalowy. Widoczne to jest w stopniu wykorzystania maszyn parowych przypadających na 1000 pracowników zatrudnionych przemyśle. To właśnie górskie regiony Alp, Sabaudii, Pirenejów posiadają największy współczynnik mechanizacji (ponad 50 maszyn na 1000 pracowników).

W drugiej fazie koncentracji przemysłu oprócz węgla dużą rolę odegrała baza wodnoenergetyczna. Doprowadziła ona na początku XX w. do powstania dużych konurbacji przemysłowych w północnych Alpach, gdzie powstały fabryki papieru oraz zakłady elektrochemiczne i elektrometalurgiczne. Wokół tych centr przemysłowych rozwinął się przemysł mechaniczny, wytwarzający wyposażenie dla fabryk. Centra te były stymulowane przez urbanistyczne obszary Sabaudii i Delfinatu, które stały się ośrodkami inicjatywy ekonomicznej i intelektualnej. W Pirenejach i Masywie Centralnym, z powodu braku zaplecza ludzkiego, przemysł ograniczył się tylko do hydroenergetyki i przemysłu gumowego w Clermont-Ferrand.

Innymi ośrodkami przemysłowymi były przemysłowe kompleksy wewnątrz dużych miast. 

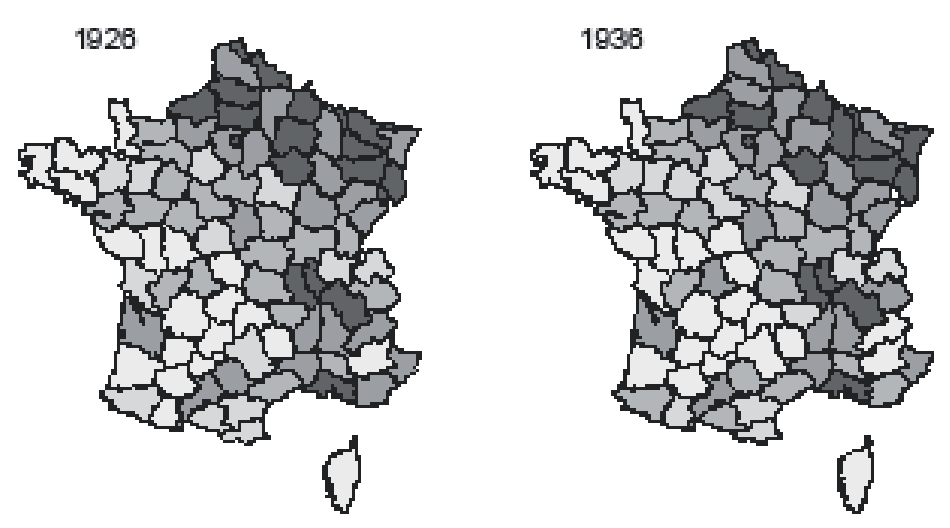

udział zakładów

$\mathrm{W} \%$

poniżej 0.1

$0.10-0.15$

$0.15-0.25$

$0.25-0.55$

| powyżej 0.55

Ryc. 6. Udział zakładów z wielkością zatrudnienia powyżej 1000 osób we Francji wg departamentów w 1909 r.

Źródło: Obliczenia własne na podstawie „Annuaire Statistique”

W Paryżu do XVIII w. tylko około 5,5\% ogółu ludności Paryża (22 tys. mieszkańców) zajmowała się rzemiosłem. Produkowano głównie towary luksusowe dla potrzeb dworu: ubrania, ozdoby, materiały dekoracyjne, meble, lustra, gobeliny itp. Innym sektorem rozwiniętym w stolicy był przemysł chemiczny. Bazował on na wiedzy oraz na materiałach dostarczanych przez środowisko urbanistyczne. Powstał tu przemysł kosmetyczny, tekstylny, budowniczy, następnie spożywczy (rafinerie buraka cukrowego), metalurgiczny (broń, części maszyn i narzędzia). Ostatecznie koncentracja sieci kolejowej zadecydowała o przemysłowym rozwoju Paryża. Pod koniec XIX i na początku XX w. rozwinął się w Paryżu przemysł środków transportu (samochodowy, lotniczy), fotograficzny, farmaceutyczny, chemiczny i spożywczy. W okresie I wojny światowej w wyniku zajścia przez Niemców przemysłowych terenów północno-wschodnich, w Paryżu skupiła się 1/4 przemysłu zbrojeniowego Francji.

Innymi urbanistycznymi regionami przemysłowymi Francji były kompleksy Marsylii i Lyonu. W Marsylii rozwinął się przemysł związany z importowanymi drogą morską surowcami. Był to przemysł spożywczy (rafineria trzciny cukrowej, młyny zbożowe), przemysł kosmetyczny, chemiczny (siarka, miedź) oraz przemysł ceramiczny. W Lyonie dominował przemysł włókienniczy oraz związany z nim przemysł chemiczny, a na ich bazie branże farmaceutyczne, fotograficzne i metalurgiczne.

Pod względem zatrudnionych w przemyśle najbardziej uprzemysłowiony był region Nord i paryski. Tworzą one razem obszar rozciagający się od departamentów regionu Paryża na północ po Górną Normandię i Flandrię oraz na wschód po Szampanię i Ardeny, posiadający udział ludności przemysłowej powyżej 55\% zawodowo czynnych. Pozostałymi regionami były: Lotaryngia, region Lyonu i Marsylia.

Po pierwszej wojnie światowej nastąpiła dalsza koncentracja przemysłu w regionie północno-wschodniej Francji. Według liczby zatrudnionych, przemysł skoncentrowany był w regionie Nord i paryskim, Alzacji i Lotaryngii oraz regionie Lyonu i wschodniej części Prowansji.

Według normalizowanego wskaźnika uprzemysłowienia, regiony przemysłowe Francji skupiały się w czterech regionach. Najbardziej uprzemysłowiony był region północny obejmujący Flandrię, Pikardię, Île-de-France oraz Górną Normandię-Dolinę Sekwany. Na wscho- 
dzie występował region złożony z Ardenów i Szampanii oraz Lotaryngii i Alzacji. Trzecim regionem był region Lyonu i St-Étienne oraz obszary alpejskie i doliny Saony. Na południu wyróżniał się obszar Prowansji z Marsylią i ujściem Rodanu. Pozostałe regiony związane były z portami Nantes, Bordeaux czy ośrodkami miejskimi, takimi jak Tuluza.

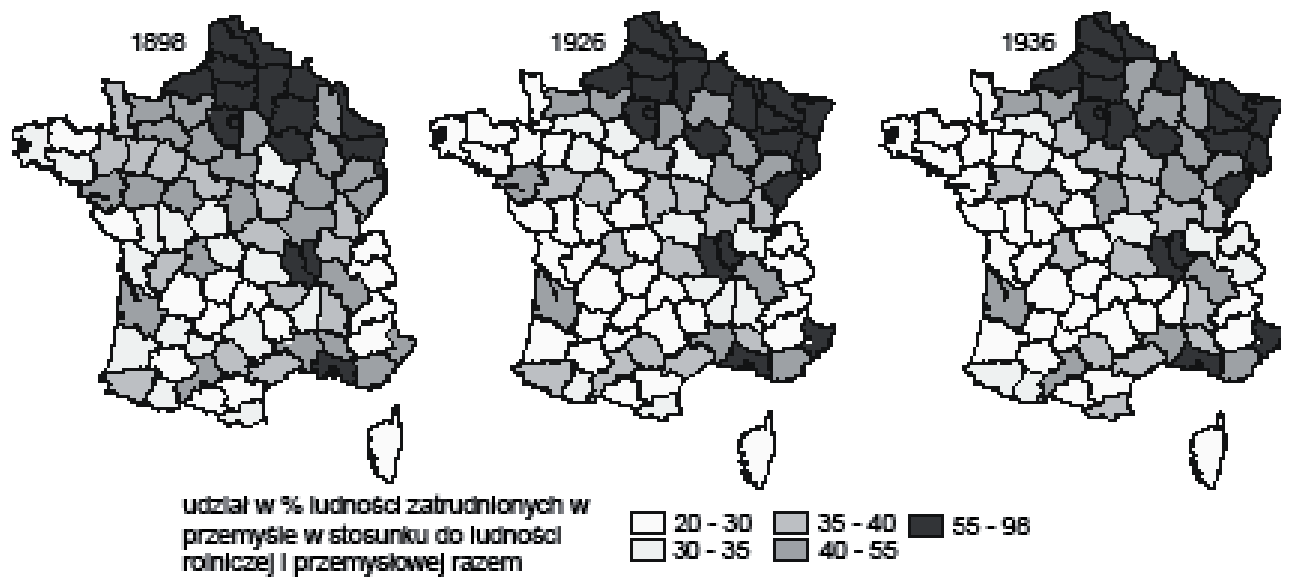

Ryc. 7. Udział zatrudnienia w przemyśle we Francji

Źródło: Obliczenia własne na podstawie „Annuaire Statistique”

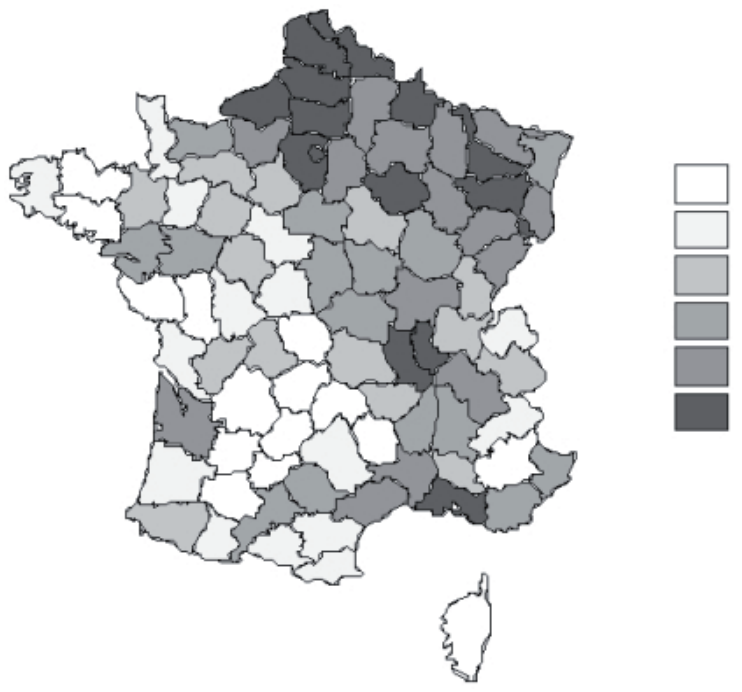

-0.68 do -0.45

-0.45 do -0.33

-0.33 do -0.17

-0.17 do 0.04

0.04 do 0.60

0.60 do 3.59

Ryc. 8. Standaryzowany wskaźnik uprzemysłowienia Francji

wskaźnik wyliczono według następującej formuły: ti =1/n $\Sigma$ tij, gdzie: $\mathrm{n}$ - liczba przyjętych cech; ti - wskaźnik syntetyczny dla i-tego departamentu; tij - zestandaryzowana wartość j-tej cechy dla i-tego departamentu; standaryzacje przeprowadzono według wzoru: tij = xij - xj/sj, gdzie: $x i j-$ wyjściowa wartość j-tej cechy dla i-tej jednostki; $x j, s j$ - odpowiednio średnia arytmetyczna i odchylenie standardowe j-tej cechy; 
Po drugiej wojnie światowej w celu rozwoju gospodarki oraz aktywizacji obszarów zacofanych i zrównoważonego rozwoju w 1956 r. przeprowadzono podział Francji na 22 regiony, które pogrupowano ze względu na podobieństwo i powiązania przemysłowe. Regiony te były podstawą do wyodrębnienia administracyjnych regionów Francji w 1982 r. Jednakże zróżnicowanie w przestrzennym rozwoju przemysłu jest dalej widoczne. Przemysł nadal skupia się w północno-wschodniej części kraju wokół dużych ośrodków miejskich. Jedynie przemysł wysokich technologii, dzięki ingerencji państwa, rozwinął się w Basenie Akwitańskim w południowo-zachodniej części kraju.
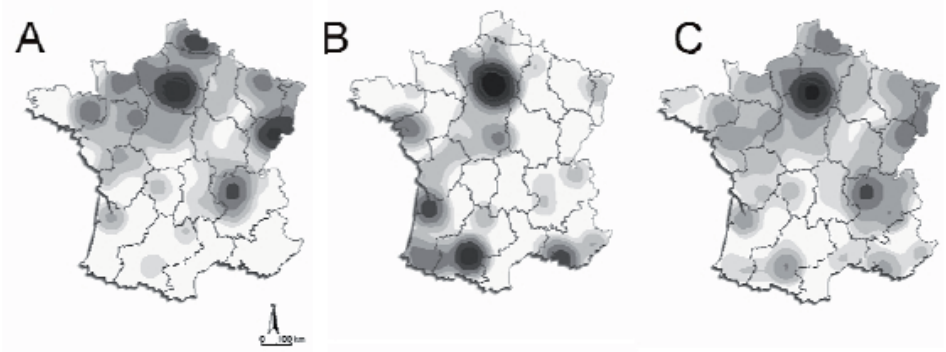

liczba pracujących w \%o zatrudnionych $\mathrm{w}$ ogóle $\mathrm{w}$ danym sektorze w gospodarce narodowej
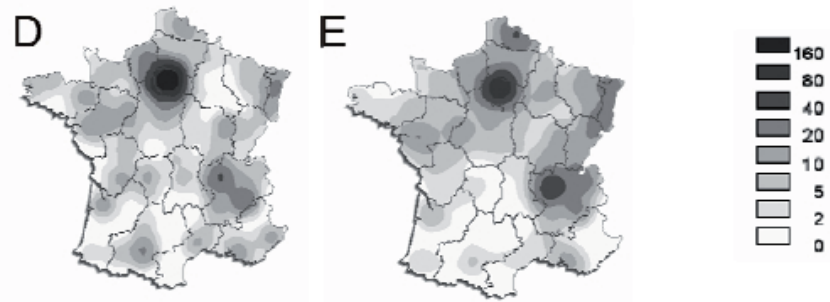

Legenda

A) p. samochodowy,

B) p. lotniczy i kosmiczny

C) p. precyzyjny

D) p. elektryczny i elektromaszynowy

E) p. maszynowy

Ryc. 10. Potencjał pracujących w przemyśle w $2000 \mathrm{r}$.

Źródło: INSEE 2000

\section{Literatura}

Braudel F., 1992, Kultura materialna, gospodarka i kapitalizm XV-XVII w, t. III: Struktura codzienności, Warszawa

Cobban A., 1965, A history of modern France, Vol. 1: 1715-1799, Harmondsworth

Duby G., 1958, Histoire de la civilisation française moyen âge-XX siècle, Paris

Dunham A.L., 1953, La révolution industrielle en France (1815-1848), Paris

Fajferek A., 1964, Region ekonomiczny oraz metody analizy regionalnej, Zeszyty Naukowe, seria specjalna: Rozprawy Habilitacyjne Nr 6, Wyższa Szkoła Ekonomiczna w Krakowie, Kraków

Maciejewski M., 1996, Powszechna historia gospodarcza czasów nowożytnych, Wrocław

Planhol de X., 1994, An historical geography of France, Cambridge University Press

\section{The creation of industrial regions of France}

The subject of the article is the process of creating industrial regions of France. On the basis of statistical data and referring to the number of employees in the industry, the number of industrial plants and the dimension of industrial production, an attempt at industrial regions delimitation has been made. 
Workshops dominated industrial activity up to the $19^{\text {th }}$ century. They were mostly situated in densely populated northern parts of France.

The factor which initiated the process of industry concentration was the invention of the steam engine. This dependence of industry on the steam engine and coal caused industry concentration in the regions which were rich in natural resources and trained manpower.

In the second phase of industry concentration water-energy basis played the main role. It led to the creation of large industrial centres in the mountains and around big cities.

Due to the industrial growth index the industrial centres of France were situated in four regions. The most industrialized region was the North, covering Flandres, Picardy, Île-de-France and Upper Normandy - the Seine Valley. The eastern region covered Ardenne, Champagne, Lorraine and Alsace. The third region was Lyon and St-Étienne and the regions of the Alps and the Saone Valley. In the south the regions of Provence with Marseille and the Rhone estuary were standing out. 